\title{
Perspectives on Germplasm
}

\author{
Edward J. Ryder \\ US Department of Agriculture-Agricultural Research Service, 1636 E. Alisal St., Salinas, CA 93905
}

The value of germplasm has been described in various ways: as the raw material, or the life blood, of plant breeding, as the key to the maintenance of diversity of living forms on earth, as an indicator of the origin of cultivated species. This paper will focus primarily, but not completely, on the first description, that germplasm serves as the source of genes for disease resistance, for environmental adaptation and tolerance, for yield improvement, for appearance and beauty, and other traits that enable plant breeders to bring about the improvement of our crop species and thereby insure the continued productivity of agriculture including horticulture. Of course, the ultimate goal is the availability, of generous supplies of food, feed, fiber, and ornament for the people of the world.

The conversion of the human life style from the hunter-gatherer phase to the more sedentary production of food, or agriculture, is commonly accepted to have taken place about 10 millenia ago. At that time, everything that grew was germplasm, because there were no named cultivars. It was the beginning. In modern times, we tend to think of germplasm as consisting of landraces and wild forms introduced into the mainstream of breeding and production and that cultivars are the settled forms that are to be changed by the introduction of genes from new, not quite ready for prime time, forms. But, in fact, germplasm is still everything that grows. Our sources of genetic variation are domestic, modern, and heirloom cultivars, cultivars and landraces from somewhere else, genetic stocks, and wild relatives, both near and distant. We also should add to that list the accumulating stocks of DNA in various libraries.

This paper is divided roughly into three parts. The first is historical, to chronicle some of the notable events of the past, to assess their significance, and to set the stage for the activities of the present and of the future. The second part is a discussion of the important aspects of modern germplasm activity: collection, storage, evaluation, application, and distribution. The third part is an assessment of modern trends in germplasm acquisition and plant breeding and how they may impact upon the future.

\section{EARLY HISTORY OF AGRICULTURE AND GERMPLASM}

The very early years of the beginnings of agriculture are understandably difficult to chronicle. How, and why does one become a farmer? Perhaps someone noted that a stand of plants with grains or fruit bore edible materials over and over again. Someone else may have found that seeds could be saved. Others may have discovered that it was easier to stay in one place than to move about constantly. Increasingly sophisticated tools for planting, cultivating, and harvesting would be developed. Structures for seed storage, and methods for confining animals for domestication would follow. The perception that some plants performed better than others would lead to selection and the development of the first identifiable varieties. These would also become desirable for trading and therefore the movement of early germplasm from one location to another would be the rudimentary beginning of germplasm exploration and acquisition.

Documented collection trips came later. One of the earliest known is a collecting trip sent by Queen Hatshepsut of Egypt to an almost legendary place called Punt to collect incense trees for the royal gardens. This occurred about 1500 BC (Fig. 1). Thutmose III, Pharoah after Hatshepsut, sent a collecting trip to Syria, in about 1450 BC, which brought back seeds, fruit, and plants of various species (Fig. 2).

Over the ensuing centuries, plants and animals were transported from place to place. For example, lettuce (Lactuca sativa) probably originated in the Middle East and traveled to Egypt, where it was first recorded in tomb paintings during the Fourth Dynasty of the Old Kingdom, about 2500 BC (Fig. 3) (Keimer, 1924; Harlan, 1986). It moved around the Mediterranean Basin and was recorded in Persia (550 BC) and Greece (430 BC). It was recorded in Rome (164 AD), where it became very popular. There were several named varieties of different types. It was

Fig. 1. Temple wall drawing of two ships of Queen Hatshepsut's fleet showing incense trees being loaded on board.
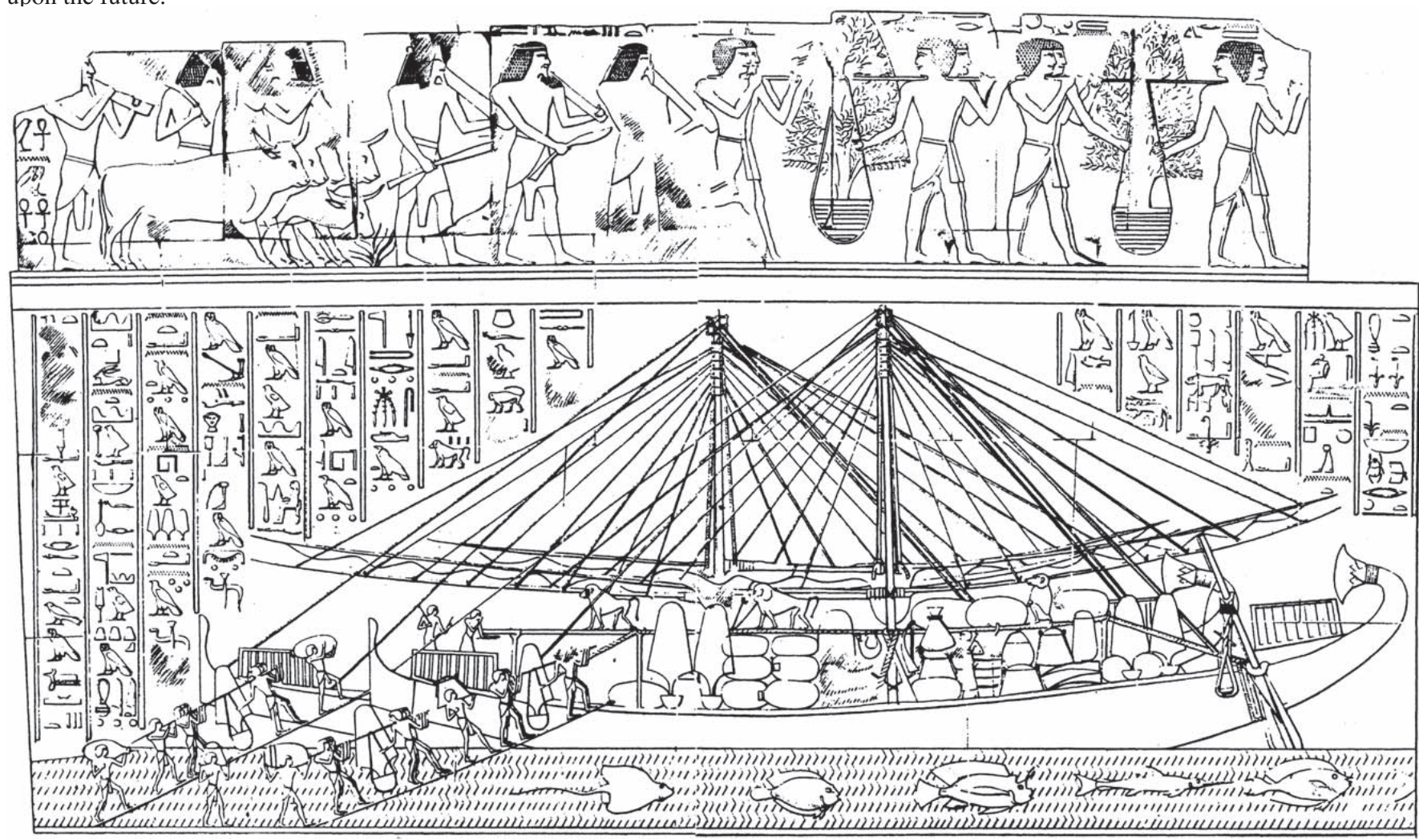


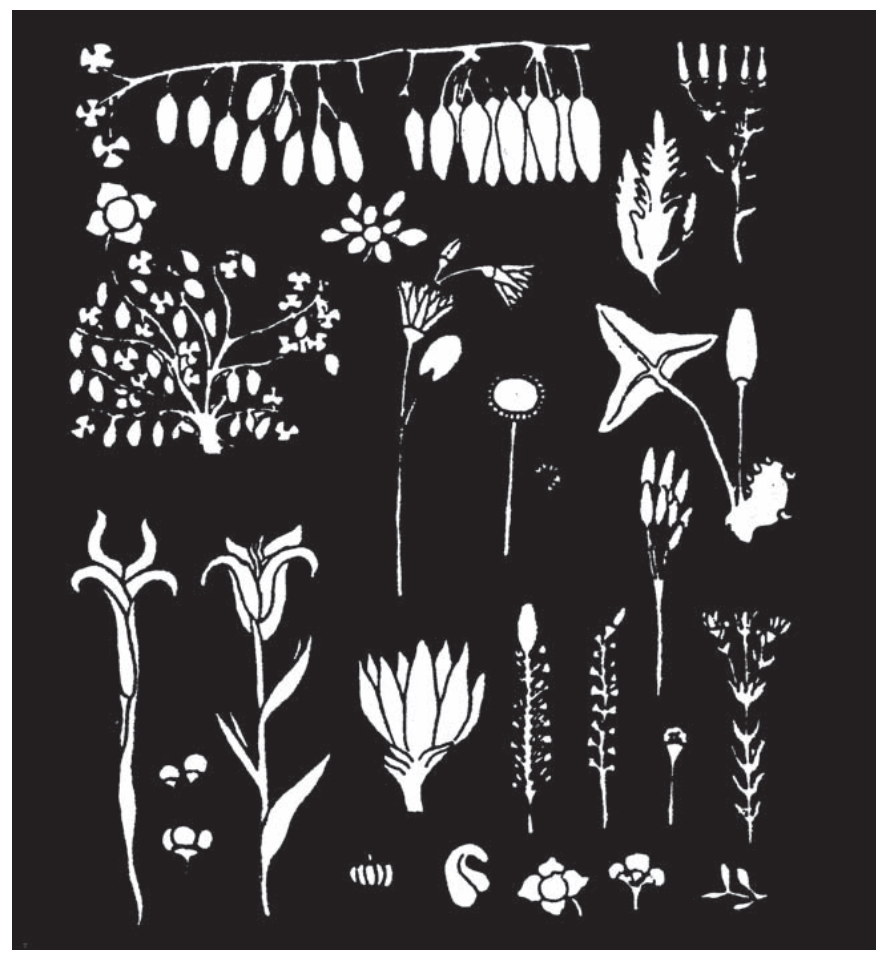

Fig. 2. Temple wall drawing of seeds and plants from Syria, obtained by Thothmes III during an expedition about $1450 \mathrm{BC}$.
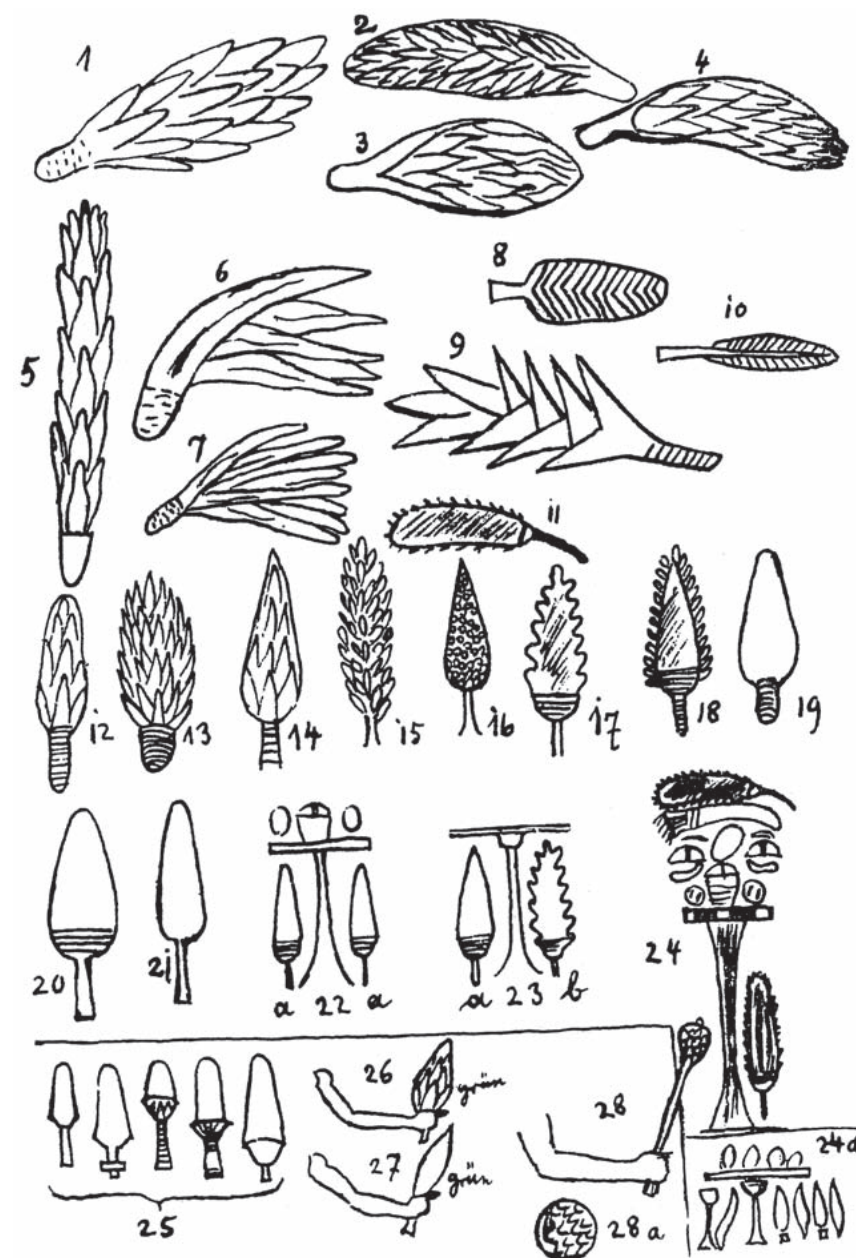

Fig. 3. Depictions of lettuce plants from various Egyptian tomb paintings, beginning about 4th Dynasty with realistic drawings (top) to later dynasties with increasingly stylized drawings (bottom). apparently taken to Avignon, France in the early 14th century by the first of nine Popes that resided in that city. It probably came to the New World as early as the second voyage of Columbus in 1494 (Sturtevant, 1972, Ryder, 1999).

In the 17th and 18th centuries, there was great germplasm activity worldwide, including the collection of plants in diverse places, carrying of seeds and plants to newly settled areas, and establishment of exotic species in botanical and horticultural gardens. Collection in East Asia began in the mid 18th century, but it was not until the forced opening of China and Japan in the mid 19th century that the trickle of mostly herbaceous and woody ornamental species to Western countries became a flood. Many noted collectors, including Robert Fortune, Phillip von Siebold, Charles Rogers Hall, E.H. Wilson, and Charles S. Sargent collected in Asia, and brought to Western Europe and the U.S. many ornamental trees and shrubs (Spongberg, 1993).

\section{SYSTEMIZATION OF GERMPLASM ACTIVITIES}

In the 19th century, the various aspects of germplasm discovery, collection, and use became more and more systemized as governments assumed responsibility, once having recognized the commercial and scientific value of the world's plant populations. In the United States, in 1819, American consuls overseas were asked to collect seed of potentially useful plants and send them home. The U.S. Patent Commissioner administered plant introduction activities from 1836 to 1862, when the United States Department of Agriculture (USDA) was established and took charge. Finally, in 1898, the Plant Introduction Office was established.

\section{GERMPLASM IN THE 20TH CENTURY}

The concepts and the purview of germplasm broadened in the 20th century. Previously, the identification, collection, and placement of new plants were the main activities of those involved. These activities of course continued, with a great deal of exploration for about forty years until curtailed by World War II.

The heyday of the plant explorer was in the early part of the 20th century. Two of the most famous in the U.S. were David Fairchild and Frank N. Meyer. Fairchild was appointed, in 1898, to head the newly created Section of Foreign Seed and Plant Introduction of the USDA. He spent 37 years traveling the world and brought back a number of plants that became economically important, including mango, alfalfa, nectarine, date, horseradish, bamboo, and flowering cherry. One of Fairchild's first acts was to hire Meyer as a plant explorer. Meyer collected extensively in China and was renowned for his long trips on foot.

Other changes were also occurring: 1) increasing systemization of germplasm conservation - collection, storage, evaluation, distribution, and use, 2) the increasing importance of the research aspects of germplasm, with interest in the geographical distribution and evolutionary origins of plant species, the genetic basis for collection and storage decisions, and the basis for longevity in storage; and 3) in more recent years, the political ramifications of collection in one location and use in another and the place of germplasm in the thicket of intellectual property rights.

\section{THE LEGACY OF N. I. VAVILOV}

Perhaps the greatest impetus to the advancement of germplasm on all fronts, scientific as well as discovery, was given by Nikolai I. Vavilov. I find no difficulty in comparing his accomplishments and vision to those of Charles Darwin. Darwin's theory of the origin of species was formed during his voyage of discovery on the Beagle and matured after his return to England. Vavilov also traveled, to collect plants in China, Afghanistan, Abyssinia (Ethiopia), Central America, and South America, in a series of journeys from 1923 to 1931 . He visited 60 countries, as well as all parts of the former Soviet Union, collected thousands of plants, observed the distribution of species, and developed his theories of the law of homologous series and of the centers of origin of cultivated plants (Vavilov, 1951). He formalized the reasons that collected plants were important to advance plant breeding. At the same time, he recognized the importance of local varieties, which we now call landraces, as sources of variation. He formulated a basis for plant introduction, from his understanding that the species of the world are not distributed uniformly. He 
cited the importance of wheat varieties from Russia that were brought into the United States and enabled Americans to eat decent bread. In the words of a USDA official: "We were eating almost tasteless bread here, ignorant of the fact that most of Europe had a better flavored bread with far higher nutritive qualities than ours." At the same time, Vavilov recognized that the transfer of germplasm took place in two directions, writing: "It is difficult to imagine our existence today without such crops as the sunflower, corn, potato, tobacco, and upland cotton, all of which were imported not long ago from America."

\section{CENTERS OF ORIGIN}

Although Alphonse de Candolle (1883) first alluded to the places where cultivated plants originated, it was Vavilov who organized observations and information in a meaningful way. His Centers of Origin theory was first formulated in 1926, and later modified and expanded in 1931 and 1951. It stated that there were eight independent regions where various plants were first cultivated (Table 1). The largest was in the mountainous regions of central and western China and included 136 species of cereals and other grains; bamboos; root, bulb, and tuber crops; vegetables; temperate, tropical, and subtropical fruit; sugar, oil, resin, and tannin plants; spices; industrial crops; fiber crops; dye crops; and medicinal crops. The second largest was the Indian region (excepting the northwest area), with 117 species. A sub center was in the Indo-Malayan region. Others in Asia were in Central Asia (including northwest India) and the Near East. Far- ther west was a region around the Mediterranean Sea, and in Africa, the Abyssinian (Ethiopian) Center. In the New World, there were two centers, the Central American Region, and the South American Region, and two subcenters in Chile and Brazil-Paraguay. He also proposed that for many crops, there were secondary as well as primary centers.

The Centers of Origin concept was modified later by others, especially by Jack R. Harlan (Harlan, 1975). Harlan proposed three independent systems, each consisting of a well defined center and a noncenter. The latter covered a wide area, and was essentially unbounded and diffuse. The systems included 1) a Near East center and an African noncenter, 2) a North Chinese center and a South East Asian and South Pacific noncenter, and 3) a Meso-American center and a South American noncenter.

\section{A NATIONAL PLANT GERMPLASM SYSTEM}

In 1946, a national plant germplasm system for the United States began to take shape, under the Agricultural Marketing Act, which authorized the establishment of its components. The first major step took place in 1948 with the establishment of the Plant Introduction Stations, whose function was to acquire, store, describe, replenish, and distribute seed of the major and many minor crops grown the United States, as well as their wild relatives. These were distributed over the climatic regions of the country. At the present time, there are four Regional Plant Introduction Stations: in Geneva, N.Y.; Ames, Iowa; Pullman, Wash.; and Experiment, Ga. In 1958, the National Seed Storage Laboratory (now

Table 1. The centers of origin of cultivated plants. Some crops shown in more than one center (From Vavilov, 1951).

\begin{tabular}{|c|c|c|c|c|}
\hline No. & Name & Region & No. species & Selected crops \\
\hline $\bar{I}$ & Chinese & Mountainous regions, central and western China & 136 & $\begin{array}{l}\text { Soybean, cowpea, bamboo, yam, radish, pak-choi, } \\
\text { eggplant, pear, apricot, walnut, orange, persimmon, } \\
\text { tea, ginseng }\end{array}$ \\
\hline II & Indian & Central and north India, Burma, Assam & 117 & $\begin{array}{l}\text { Rice, sorghum, chickpea, mung, cowpea, mango, } \\
\text { cucumber, sugarcane, mustard, jute, indigo, } \\
\text { black pepper }\end{array}$ \\
\hline IIa & Indo-Malayan & Malaya, Borneo, Java, Philippines, Indo-China & 55 & $\begin{array}{l}\text { Banana, pummelo, cocoanut, cardamom, clove, } \\
\text { durian, ginger }\end{array}$ \\
\hline III & Central Asian & $\begin{array}{l}\text { Punjab, NW India, Kashmir, Afghanistan, } \\
\text { Uzbekistan, Tadjikistan, western China }\end{array}$ & 42 & $\begin{array}{l}\text { Wheat, rye, pea, hemp, } \\
\text { cotton, carrot, turnip, garlic, spinach, basil, } \\
\text { pistachio, almond }\end{array}$ \\
\hline IV & Near Eastern & Asia-Minor, Iran, Transcaucasia, Turkmenistan & 83 & $\begin{array}{l}\text { Wheat, rye, oats, lentil, alfalfa, vetch, flax, rape, } \\
\text { fig, anise, melon, pumpkin, cabbage, lettuce }\end{array}$ \\
\hline V & Mediterranean & Mediterranean basin & 84 & $\begin{array}{l}\text { Wheat, lupine, clover, mustard, olive, beet, } \\
\text { leek, artichoke, lettuce, asparagus, celery, } \\
\text { fennel, parsley, thyme, sage, hop }\end{array}$ \\
\hline VI & Abyssinian & Ethiopia, Somalia, Eritrea & 38 & Wheat, pearl millet, coffee, okra, myrrh, castor bean \\
\hline VII & Central American & Mexico, Central America, Antilles & 49 & $\begin{array}{l}\text { Corn, bean, lima, chayote, sweet potato, pepper, } \\
\text { cotton, papaya, guava, cashew, cactus, cacao }\end{array}$ \\
\hline VIII & South American & Peru, Ecuador, Bolivia & 45 & $\begin{array}{l}\text { Potato, quinoa, pumpkin, marigold, cotton, } \\
\text { quinine, tobacco }\end{array}$ \\
\hline VIIIa & Chiloe & Chile & 4 & Potato, strawberry \\
\hline VIIIlb & Brazilian-Paraguayan & Brazil, Paraguay & 13 & Manioc, peanut, rubber \\
\hline
\end{tabular}

Table 2. The National Plant Germplasm System.

\begin{tabular}{|c|c|c|}
\hline Component & Location & Mission \\
\hline National Center for Genetic Resources Preservation & Fort Collins, Colo. & Hold backup samples, seed storage research. \\
\hline Regional Plant Introduction Stations & $\begin{array}{l}\text { Geneva, N.Y., Ames, Iowa, Griffin, Ga., } \\
\text { Pullman, Wash. }\end{array}$ & $\begin{array}{l}\text { Curate plant introductions, cultivars, working collections } \\
\text { for evaluation and distribution. }\end{array}$ \\
\hline National Germplasm Research Laboratory & Beltsville, Md. & $\begin{array}{l}\text { Coordinates plant exploration, maintains GRIN, catalogs } \\
\text { accessions, assists CGCs. }\end{array}$ \\
\hline $\begin{array}{l}\text { Germplasm Resources Information Network, } \\
\text { Data Base Management Unit }\end{array}$ & Beltsville & $\begin{array}{l}\text { Develops and maintains an automatic data retrieval system } \\
\text { for collection and dissemination of germplasm information. }\end{array}$ \\
\hline Plant Germplasm Quarantine Center & Beltsville & Monitors incoming plant materials. \\
\hline Plant Exchange Office & Beltsville & $\begin{array}{l}\text { Procure plant germplasm, prioritizes needs, } \\
\text { arranges exploration trips. }\end{array}$ \\
\hline Crop Germplasm Committees & Various & $\begin{array}{l}\text { Monitors state of crop collections; recommends } \\
\text { evaluation proposals, exploration. }\end{array}$ \\
\hline Genetics and Crop Stock Centers & $\begin{array}{l}\text { Aberdeen, Id., Urbana, Ill., Davis, Calif., } \\
\text { Pullman, Wash., Tucson, Ariz., College } \\
\text { Station, Texas, Columbus, Ohio, Palmer, } \\
\text { Ark., Parlier, Calif., Oxford, N.C., Sturgeon } \\
\text { Bay, Wis., Lexington, Ky., Salinas, Calif. }\end{array}$ & $\begin{array}{l}\text { Wheat, maize, tomato, pea, desert legumes, barley, cotton, } \\
\text { herbaceous ornamentals, arctic plants, arid land plants, } \\
\text { soybean, tobacco, potato, small grains, clover, lettuce. }\end{array}$ \\
\hline National Germplasm Repositories & $\begin{array}{l}\text { Brownwood, Texas, Corvallis, Ore., Davis, } \\
\text { Calif., Geneva, N.Y., Hilo, Hawaii, Mayaguez, } \\
\text { P.R., Miami, Fla. }\end{array}$ & Curate clonally propagated crops. \\
\hline
\end{tabular}


called the National Center for Genetic Resources Preservation) was established, with the responsibility for long-time storage of cultivars of the various crop species, as well as to perform storage related research. The National Plant Germplasm System was formally established in 1974 (Table 2).

As a result of the southern corn leaf blight (Helminthosporium maydis) epiphytotic in 1969-70, the concept of genetic vulnerability was developed, stating that crops built on a narrow genetic base were subject to extensive damage by diseases or insects. The Secretary of Agriculture appointed a National Plant Genetic Resources Board in 1975. Its job was to marshal ideas, recommend policies and actions designed to maximize germplasm conservation, recommend policies to improve security measures against diseases and insects, and help find ways to improve methods of plant collection and use. One of its actions was to initiate the appointment of Crop Advisory Committees (later Crop Germplasm Committees) to monitor the germplasm activity status of the various crop species (Table 3).

A key aspect of the system, tying all facets of germplasm together through the availability of computerized information, was the Germplasm Resources Information Network (GRIN). GRIN was the product of a study by the Germplasm Resources Information Project begun in 1977 as a joint function of USDA-Agricultural Research Service (ARS) and the Laboratory for Information Science in Agriculture (LISA) at Colorado State University. It later came under complete control of ARS.

On a world scale, the International Board for Plant Genetic Resources was founded in 1974 by the Consultative Group on International Agricultural Research, an arm of the Food and Agriculture Organization of the United Nations. Its mission was to promote an international network of genetic resource centers to further germplasm activities through the world (Table 4).

\section{SCIENCE BASED GERMPLASM ACTIVITIES}

Turning to scientific studies of the various aspects of germplasm, there are five areas of particular interest that will be briefly discussed here. One is the evolution of crop plants, emphasizing the relationship of cultivated forms to their wild relatives and of modern cultivars to heirlooms and landraces. Second is the basis of sampling from populations in the wild. Third is sampling from a collection and the concept of core collections. Fourth is research into conditions of storage, to maximize the length of the storage period, maintain seed quality, and minimize storage expense. The fifth category is the use of germplasm in crop improvement.

\section{EVOLUTION OF CROP PLANTS}

Vavilov's development of his Centers of Origin theory is based upon three phenomena: 1) the concentration of cultivated species in certain regions, 2) the existence, in most cases, of related wild species in those areas, and 3) the presence of many varieties of each species (Vavilov, 1951). These are obviously sequential phenomena, beginning with origin of species, the selection of some of these for cultivation, and the development of varieties reflecting the perception of desirability of various forms. He found that, in many cases, cultivated species remained in the original centers, while others, which may have seemed more interesting to travelers, were transported to other, secondary centers. It was noted that the primary centers were separated by often vast deserts and mountain ranges that allowed the species to develop over long periods of time, relatively undisturbed by human travel and commerce.

Numerous papers, monographs, and books have been written about the evolution, genetics, and breeding of individual crop species, often with a discussion of what is known of the related species and the ways in which introduced materials have been used in breeding. An excellent overview of these individual histories appears in Evolution of Crops (Smartt and Simmonds, 1995).

\section{SAMPLING PROCEDURES}

A major problem for the plant collector is deciding upon the size of sample to take from a given location. There are many obvious considerations, including the amount of time available, distance to

Table 3. Crops monitored by crop germplasm committees

Fruits and nuts: apple, Juglans, stone fruit, tropical fruit and nuts, small fruit, citrus, pear, grape, Carya

Cereals and grasses: wheat, rice, sorghum, grass, oat, maize, barley

Agronomic: sugarcane, sugarbeet, cotton, new crops, sunflower, tobacco, clover and pasture legumes, peanut, cool season food legumes, alfalfa, soybean

Vegetables: potato, pepper, Vigna, root and bulb, Phaseolus, cucurbit, pea, leafy vegetables, tomato, crucifers, sweetpotato

Ornamentals: herbaceous ornamentals, woody landscape

Table 4. International agricultural research centers under auspices of the Consultative Group on International Agricultural Research.

\begin{tabular}{|c|c|c|}
\hline Name and acronym & Location & Mission \\
\hline Centro Internacional de Agricultura Tropical (CIAT) & Cali, Colombia & $\begin{array}{l}\text { Crop improvement for lowland tropics of Latin } \\
\text { America. Rice, beans, cassava, forages, pasture. }\end{array}$ \\
\hline Center for International Forestry Research (CIFOR) & Bogor, Indonesia & $\begin{array}{l}\text { Research on forestry issues related to agriculture } \\
\text { and sustainable land use. }\end{array}$ \\
\hline Centro Internacional de Mejoramiento de Maiz y Trigo (CIMMYT) & Mexico City, Mexico & $\begin{array}{l}\text { Research on maize, wheat, barley and triticale } \\
\text { for food production in developing countries. }\end{array}$ \\
\hline Centro Internacional de la Papa (CIP) & Lima, Peru & Improvement research on potato and sweet potato. \\
\hline Iinternational Plant Genetic Resources Institute (IPGRI) & Rome, Italy & $\begin{array}{l}\text { Conservation of gene pools of current and } \\
\text { potential crops. }\end{array}$ \\
\hline International Center for Agricultural Research in the Dry Areas (ICARDA) & Aleppo, Syria & $\begin{array}{l}\text { Improving farm systems in North Africa and } \\
\text { West Asia. Wheat, barley, chickpea, lentil, } \\
\text { pasture legumes, small ruminants. }\end{array}$ \\
\hline International Center for Living Aquatic Resources Management (ICLARM) & Manila, Philippines & Research on fisheries culture. \\
\hline International Centre for Research in Agroforestry (ICRAF) & Nairobi, Kenya & Research on integrating trees into land-use systems. \\
\hline International Crops Research institute for the Semi-Arid Tropics (ICRISAT) & Andhra Pradesh, India & $\begin{array}{l}\text { Crop improvement of sorghum, millet, } \\
\text { chickpea, pigeonpea, groundnut. }\end{array}$ \\
\hline International Food Policy Research Institute (IFPRI) & Washington, D.C. & $\begin{array}{l}\text { Policies for meeting food needs of } \\
\text { developing countries. }\end{array}$ \\
\hline International Irrigation Management Institute (IIMI) & Colombo, Sri Lanka & $\begin{array}{l}\text { Irrigation performance, systems, facilities and } \\
\text { water management in developing countries. }\end{array}$ \\
\hline International Institute of Tropical Agriculture (IITA) & Ibadan, Nigeria & $\begin{array}{l}\text { Humid crop improvement. Maize, cassava, } \\
\text { cowpea, plaintain, soybean, rice, yam. }\end{array}$ \\
\hline International Livestock Research Institute (ILRI) & Nairobi, Kenya & $\begin{array}{l}\text { Control of major livestock diseases in } \\
\text { sub-Saharan Africa. }\end{array}$ \\
\hline International Rice Research Institute (IRRI) & Manila, Philippines & Global rice improvement. \\
\hline International Service for National Agricultural Research (ISNAR) & The Hague, Netherlands & $\begin{array}{l}\text { Strengthening and developing national } \\
\text { agricultural research systems. }\end{array}$ \\
\hline West African Rice Development Association (WARDA) & Bouake, Cote d'Ivoire & Rice improvement in west Africa. \\
\hline
\end{tabular}


be traveled, the capacity for carrying materials, the need to return for identified material when it is setting seed, and similar mundane things. Often, the decision is to collect whatever is found. One can also consider sample size from a theoretical standpoint (Namkoong 1988). Specifically, what sample size minimizes, with acceptable limits, the chance of losing useful, or potentially useful alleles? A rare allele can be easily lost unless the sample is fairly large, but otherwise relatively small samples are likely to preserve the allele. One must also consider sampling extensively in a population if it appears to be heterogeneous, and divided into discernible subpopulations. Another consideration is that when a population is complex, it may be more desirable to conserve the population in situ.

Sampling within a collection, in order to accomplish a specific task, has different parameters. It is within a controlled situation; it doesn't require extensive, expensive travel; descriptors are usually available; and materials will be theoretically available forever. Collections of certain species are very large and may be expensive and time consuming to maintain. Since sample requests are often targeted to known characteristics for specific studies, curators have resorted to the core collection for study and response to requests. The core collection is a subpopulation of the whole collection, selected to contain as much of the known variability of the entire collection as possible, and minimizing redundancy of types. It is much easier and efficient to characterize the subpopulation fully, to maintain large volumes of seed, and to distribute samples frequently, and it allows the curator to put less effort in the entire collection. The core collection is also useful as the first group to test for resistance to a newly recognized disease or insect. However, the core collection may not be sufficient to find the desired trait. This means that it is still important to maintain the viability of the entire collection.

Research on storage conditions is important in order to increase the length of time that material can be stored and maintain viability, minimize expense, and maintain seed quality. An important factor of quality in the broad sense is the preservation of genetic constancy. This can be compromised in two ways: 1) genetic change in storage over time through seed degeneration and 2) changes in gene frequency when recombination and selection occur during regeneration (Roos, 1988). Point mutations are more likely to lead to permanent change than are chromosomal aberrations, which may be lethal. Gene frequency changes most often occur when samples are taken for regeneration, which reduces the probability that alleles in low frequency will be saved. Research on various parameters of storage is an important activity of the National Center for Genetic Resources Preservation.

\section{USE OF GERMPLASM IN PLANT BREEDING}

By far the greatest impact of science on the world of germplasm is in the use of the materials, in genetic studies, and especially in plant breeding. Germplasm has been used in breeding programs frequently. The following is a short list from the past century, which is illustrative for horticultural accomplishments.

Male STERILE IN ONION. One of the classic examples of the use of germplasm was involved in the creation of a male sterile onion (Allium сера) inbred. In 1925, H.A. Jones discovered in his onion breeding plot a plant, No. 13-53 in the introduced cultivar Italian Red, that was male sterile (Jones and Clarke, 1943). It was shown that the male sterility was cytoplasmic-nuclear (Smsms) and could be manipulated in such a way that it could be propagated using a maintainer line that had the recessive sterility allele but normal cytoplasm ( Nmsms). Thus was born the hybrid onion breeding procedure, from which nearly all commercial onion hybrids have been produced.

Brown bLiGHT IN LETTUCE. The burgeoning Western iceberg lettuce industry was nearly wiped out in the early 20th century by a disease of unknown origin called brown blight. I.C. Jagger was assigned by USDA to find resistance to the disease. He selected healthy plants in an infected field of the predominant cultivar, New York, from which three resistant cultivars were developed, but the bulk of resistant cultivars, collectively the Imperial cultivar group, came from a cross with a French butterhead cultivar, Blonde Chavigne (Jagger, 1940). The disease disappeared with the introduction of these cultivars, but apparently reappeared as production of susceptible romaine cultivars increased in the latter part of the century. The disease was given a new name, lettuce dieback. The cause was shown to be either of two tombusviruses, tomato bushy stunt virus and lettuce necrotic stunt virus (Obermeier et al., 2001). PI 491224, a romaine landrace, has been used as a source of resistance and selected sublines are being released as germplasm for further breeding (Grube and Ryder, 2003).

Apple sCab Resistance. One of the major apple diseases is apple scab, caused by the fungus Venturia inequalis. Resistance was found in several small fruited species related to the apple (Malus domestica) (Hough, 1944). Among them, M. floribunda was used as a source to transfer the resistance to cultivated apples. This was accomplished in a unique cooperative program among three institutions (Illinois, Purdue, and Rutgers) from different states, which was maintained through changes of personnel over a long period (Thompson, 1981).

\section{FLOWER BREEDING GERMPLASM USE}

The emphasis in flower breeding has been, understandably, more in the areas of blossom color, blossom size, and plant architecture plus introduction of new species, and less in the area of disease resistance, than in vegetable and fruit crops. Ewart (1981) described the influence of multiple species in the development of eight genera of bedding plants and seed planted flowers. For example, at least five species were involved in the development of begonias (Begonia $\times$ semperflorens-cultorum). The highly popular Rieger 'Elatior' begonias are derived from a cross between the tuberous begonia and Begonia socotrana. The popular bedding plant Impatiens wallerana became even more popular with the introduction of I. hawkeri and other species from New Guinea. Other flower crops, such as gladiolus, pelargonium, petunia, and zinnia, are all based on two or more species.

Dutch ELM DISEASE. Dutch elm disease devastated plantings of the American elm (Ulmus americana), beginning in the 1930s, and a search for resistance among plantings of the tree had only limited success. European species did have resistance and were used in Holland for development of resistant cultivars. In Ohio, a cross between a Dutch selection and an elm from Siberia led to the development of the resistant Urban elm, which was released in 1972 (Schreiber and Main, 1976).

Chestnut BLight. Another devastating tree disease, chestnut blight (Cryptophonectria parasitica), was introduced into the U.S. in the early 1900s and essentially wiped out the american chestnut (Castanea dentata) by 1950 . The most resistant related species is the chinese chestnut ( $C$. mollissima), which has been used in crosses and various breeding procedures to develop a resistant American type.

\section{WHERE ARE WE NOW?}

At this point, two questions may be asked: Where has this long history and evolution of germplasm activity led us? Where may it lead us in the future? Answers to both of these questions have biological bases with political overtones. The latter is not new. The ability of western explorers to collect in Japan and China in the 19th century was achieved by military diplomacy. During the World War II period, plant collection came to a virtual standstill in most of the world. Finally, after the war, the regime change in China severely restricted plant exploration there until about 1980.

Since World War II, we have entered a period of unprecedented population growth, urbanization, and industrial expansion, which have severely impacted collection sites all over the world, eliminating wild relatives, landraces, and probably, as yet unknown, never to be known, species. The opportunity to recollect in previously explored areas and to collect in new areas has been severely reduced. War, and the threat of war, in Afghanistan, Iraq, and the Eastern Mediterranean will make it difficult to collect because of obvious danger and of further damage to prospective collection sites.

From my own experience with lettuce and some knowledge of other collections, it appears that materials already collected are in reasonable to good shape. Using lettuce as an example, we have one of the world's largest collections in freezer storage at $-20{ }^{\circ} \mathrm{C}$. We monitor seed number and viability fairly closely and use a dedicated portion of our greenhouse, which is occupied 12 months a year with regenerat- 
ing material. We are developing a core collection. We are maintaining some redundancy within our collection, with collections in Pullman, Washington and Davis, Calif., and with collections in other countries (McGuire et al., 1993).

\section{WHO OWNS GERMPLASM?}

The political aspects of germplasm transfer and stability are generating a tremendous amount of activity on the part of scientists, legislatures, political leaders and other interested parties.

The collection of things in one country to be taken to another country is a very old practice and has included not only plant materials, but also wild animals, ancient art objects, and people. This is an assertion of imperialism, of the triumph of one sovereignty over another. In recent years, the declaration of sovereignty over their own native plant materials has been made by many countries, and was one of the major concerns of the Earth Summit in Brazil in 1992. The impetus came from charges of biopiracy, that developed countries were taking raw germplasm, transforming it into elite cultivars, and selling it back in the underdeveloped countries at prices they could not afford. This is something of an oversimplification, for various reasons, but nevertheless it became an issue. As a result some countries have closed their borders completely to plant exploration and others have insisted on some form of compensation. One outcome of the Earth Summit was the Convention on Biodiversity (CBD). The CBD specified several protocols. Authority to grant access rested solely with the country of origin. Rules for facilitating access of collectors into a country should be developed jointly and agreed to by both countries. Each country should attempt to carry out research using the collected genetic materials. Each country should develop plans and procedures for sharing the results of research and the derived benefits. Over 150 countries signed the CBD. A notable exception was the United States, primarily on the grounds that it would not provide sufficient protection for intellectual property rights (Raeburn, 1992).

\section{MAINTAINING BIODIVERSITY}

The objective of maintaining biological diversity may pit plant scientists, farmers, environmentalists, and governments against each other in various combinations in trying to decide how resources should be used: forests versus ranches, forests vs. habitats, agricultural lands vs homesites and industrial sites. The CBD addressed this by affirming that biodiversity has both intrinsic and social value, the latter including scientific, ecological, aesthetic, economic, educational, cultural, and recreational values. It affirms that each country has sovereign rights over its own biological resources and should be aware of what it has within its borders. Each country should develop strategies for conserving its biological resources, and that the plan should include setting aside protected areas and otherwise maintain diversity.

\section{LOOKING TO THE FUTURE}

Finally, it is interesting and important to consider the possibilities for the future. It also may be useful to state what ought, or ought not, to happen.

The CBD addressed two important questions: the ownership of germplasm on an international scale, and the maintenance of biodiversity in the world. Developing countries will continue to assert their sovereignty over their resources and either forbid collection trips or negotiate for some form of compensation. Hopefully, they will reach a point in their own development where they will be able exchange both natural resources and finished products freely with other countries. Habitat loss and violent conflict show no signs of abating and probably will continue. If they do, the diversity of life will certainly be impacted.

The state of existing collections is likely to continue in a reasonably stable, reasonably prosperous condition. In this country, NPGS will continue to upgrade storage conditions and preservation protocols, and facilitate evaluation studies, distribution, and application to breeding problems.

Of concern should be the relationship between germplasm and issues of intellectual property rights. When the patenting option was extended to sexually reproduced plants, permitting the protection of cultivars and biotechnological advances, it should not be surprising that applications have been advanced that stretch the meaning of the language in the law. Consider the attempt by Agracetus in 1993 to patent all genetically engineered cotton. And, in 1986, Loren Miller of International Plant Medicine Corporation received a patent for the ayahuasca vine (Banisteriopsis caapi), because of its medicinal properties. However, it seems that this vine had been processed into a ritual medicinal and spritual drink for several hundred years in the Amazon basin. After protest by the tribes and the Center for International Environmental Law, the patent was revoked, but only because the description of its use had been published. The bigger question of whether natural products should be patentable was not resolved.

This hundred year review has turned into a 10 millenium review. Perhaps instead of referring to germplasm as the lifeblood of plant breeding, it might be just as easily thought of as the lifeblood of human civilization. This awesome designation tells us that germplasm is much too important a human resource to leave its control to commercial, academic, and governmental interests alone. It is a human responsibility.

\section{Literature Cited}

De Candolle, A.P. 1883. Origine des plantes cultivees. Librairie Germer Bailliere et Cie. Paris.

Ewart, L.C. 1981. Utilization of flower germplasm. HortScience 16:135-138. Grube, R.C. and E.J. Ryder. 2003. Romaine lettuce (Lactuca sativa) breeding lines with resistance to lettuce dieback. HortScience (in press).

Harlan, J.R. 1975. Plants and man. Amer. Soc. Agron., St. Paul.

Harlan, J.R. 1986. Lettuce and the sycomore: sex and romance in Ancient Egypt. Econ. Bot. 40:4-15.

Hough, L.F. 1944. A survey of the scab resistance of the foliage on seedlings in selected apple progenies. Proc. Amer. Soc. Hort. Sci. 44:260-272.

Jagger, I.C. 1940. Brown blight of lettuce. Phytopathology 30:53-64.

Jones, H.A. and A.E. Clarke. 1943. Inheritance of male sterility in the onion and the production of hybrid seed. Proc. Amer. Soc. Hort. Sci. 43:189-194.

Keimer, L. 1924. Die Gartenpflanzen in Alten Aegypten. Hoffmann und Campe, Hamburg.

McGuire, P.E., E.J. Ryder, R.W. Michelmore, R.L. Clark, R. Antle, G. Emery, R.M. Hannan, R.V. Kesseli, E.A. Kurtz, O. Ochoa, V.E. Rubatzky, and W. Waycott. 1993. Genetic resources of lettuce and Lactuca species in California. An assessment of the USDA and UC collections and recommendations for long-term security. Rpt. 12. Univ. Calif. Genet. Resour. Conserv. Progr., Davis.

Namkoong, G. 1988. Sampling for germplasm collections. HortScience 23: 79-81.

Obermeier, C., J.L. Sears, H.Y. Liu, K.O. Schlueter, E J. Ryder, J.E. Duffus, S.T. Koike, and G.C. Wisler. 2001. Characterization of distinct tombusviruses that cause diseases of lettuce and tomato in the Western United States. Phytopathology 91:797-806.

Raeburn, P. 1992. The convention on biological diversity: Landmark earth summit pact opens uncertain new era for use and exchange of genetic resources. Diversity 8:4-7.

Roos, E.E. 1988. Genetic changes in a collection over time. HortScience 23: $86-90$.

Ryder, E.J. 1999. Lettuce, endive and chicory. CABI Publ., Wallingford, U.K.

Schreiber, L.R. and H.V. Main. 1976. Urban elm. HortScience 11:517-518.

Smartt, J. and N.W. Simmonds. 1995. Evolution of crops plants. 2nd ed. Longman, Harlow, U.K.

Spongberg, S.A. 1993. Exploration and introduction of ornamental and landscape plants from eastern Asia, p. 140-147. In: J. Janick and J.E. Simon (eds.). New crops. John Wiley and Sons, New York.

Sturtevant, E. Lewis. 1972. Edible plants of the world. U.P. Hedrick (ed.). Dover Publ., New York.

Thompson, M.M. 1981. Utilization of fruit and nut germplasm. HortScience $16: 132-135$

Vavilov, N. I. 1951. The origin, variation, immunity and breeding of cultivated plants (translated by K.S. Chester). Ronald Press, New York. 